\title{
Empowerment Program Implementation on Small and Medium Businesses Positively Influenced the Performance of the Businesses: (Study towards Small and Medium Businesses Empowered by the Cooperative and Small and Medium Office of Ogan Ilir Regency, Indonesia)
}

\author{
Andy Alfatih, Diana Dewi Sartika, Dyah Hapsari ENH
}

\begin{abstract}
The study entitled the influence of empowerment program implementation on small and medium businesses towards the performance of the businesses in Ogan Ilir Regency, Indonesia. The results indicated that the businesses performance was good. The score was 412. In addition, empowerment program implementation was scored 458. It meant also good. In terms of regression coefficient value, it was 0.502 . It implied that empowerment program implementation positively influenced the business performance. Moreover, simple regression test showed the correlation $[r]$ between the two variables was strong because the score was 0.711, lies between 0.601 - 0.800. Besides that, the correlation was positive and unindirectional. This meant that the better empowerment program implementation was, the higher the business performance would be. The value of $t$ amounted to 10,972. While the value of $t$ table was 1,657. It could be concluded that H1 hypothesis that said there was a positive and significant influence empowerment program implementation towards enterprises performance was accepted. From t test, it showed that $t>t$ table $[10,972>1,657$ at $95 \%$ of confidence degree with 120 samples, it was understood that the influence of empowerment program implementation towards enterprises performance was significant. The value of $r$ square was 0.505. It meant that the influence of empowerment program implementation towards enterprises performance was as much as $50,5 \%$. Another $49,5 \%$ was influenced by other factors $[\mathcal{E}]$ which were not examined in this research.
\end{abstract}

Index Terms: Empowerment, Enterprises Performance, implementation, Program.

\section{INTRODUCTION}

In Indonesia, small and medium businesses play extremely essential roles In economic aspect. They serve as daily needs suppliers, provide employment, play a role in the process of equity, increase the people's incomes, and to encourage national economic growth. Unluckily, most of them, - especialy in Ogan Ilir Regency, cannot play those roles well due to their less developed condition. They lack

Revised Manuscript Received on April 19, 2019.

Andy Alfatih, Public Administration Department, Universitas Sriwijaya, Palembang, Indonesia.

Diana Dewi Sartika, Sociology Department, Universitas Sriwijaya, Palembang, Indonesia.

Dyah Hapsari ENH, Sociology Department, Universitas Sriwijaya, Palembang, Indonesia. business capital, their business management systems are still poor, unattractive product packaging, and a very limited marketing system. To overcome the above problems, local government of Ogan Ilir Regency was encouraged to provide empowerment.

\section{Research Questions}

1. Was there any influence of empowerment program implementation on small and medium businesses towards the performance of the businesses?

2. How much was the influence of empowerment program implementation on small and medium businesses towards the performance of the business?

\section{The Objectives of The Research}

The purposes of this research were to find out whether there was any influence of empowerment program implementation on small and medium businesses towards the performance of the businesses. In addition, it was also to know how much the influence was.

\section{LITERATURE REVIEW}

Van Meter and Van Horn, in Wibawa, et al (1994), stated that policy implementation was deliberately used to enhance performance.

In the book of Ripley and Franklin [1986] entitled Policy Implementation and Bureaucracy, it was written that successful policy implementation was measured by some parameters. They were degree of compliance with applicable regulation, the smoothness of the routine functions, and realizing the desired target and impact.

Business performance, according to Kaplan and Norton [1996], had 3 parameters. They were finance, customer, internal process, growth and learning process. 


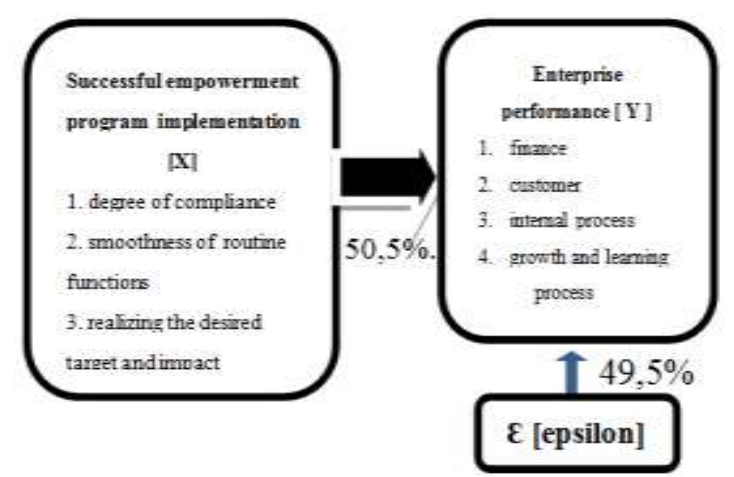

Fig. 1 Conceptual Framework

\section{RESEARCH METHOD}

The method of this research was quantitative.

Analysis Unit: The analysis and observation units were Individual, the of owners of small and medium businesses in Ogan Ilir Regency.

Operational Definition: The variables were operationalized as follows.

\begin{tabular}{|c|l|}
\hline \multicolumn{1}{|c|}{ Variables } & \multicolumn{1}{|c|}{ Dimensions } \\
\hline $\begin{array}{l}\text { Successful program } \\
\text { implementation } \\
\text { [Ripley }\end{array}$ & $\begin{array}{l}\text { degree of compliance, } \\
\text { implementation smoothness of } \\
\text { Franklin:1986] }\end{array}$ \\
\hline $\begin{array}{l}\text { Enterprise } \\
\text { performance functions, and realizing } \\
\text { and Norton: 1996] }\end{array}$ & $\begin{array}{l}\text { Finance, customer, internal } \\
\text { process, and growth and learning } \\
\text { process }\end{array}$ \\
\hline
\end{tabular}

\section{A. Population}

There were 767 owners of small and medium enterprises. From those, only 120 were under the empowerment program of the Cooperative and Small and Medium Service of Ogan Ilir Regency. The 120 empowered small and medium enterprises had been the respondents of this research.

Data Collection Techniques: Questionnaire spreading, and on the field observation.

\section{B. Instrument Validity Test}

The answers to the statements in questionnaires referred to Likert scales. They were: Very much disagree was coded 1 , disagree $>2$, neutral $>3$, agree $>4$, and very much agree $>5$. Before the questionnaire was spreaded out, it was tested for its validity by using Pearson correlation product-moment, as suggested in Riduwan (2004:216). Theoretically, the formula was as follows:

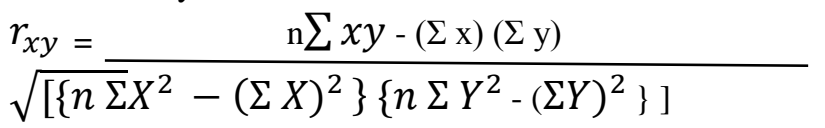

If the value of $r_{x y}$ or $\mathrm{r}$ was $>\mathrm{r}$ table, at $10 \%$ of significance $(\alpha)$, it means the item was valid.

Instrument validity test result for the variable of enterprises performance consisting of 12 questions, indicated that all items were valid. The value of $r$ ranged from 0,533 to 0,769 referring to the value of $r$ table which was 0.443 . While, variable of empowerment program implementation ranged from 0,473 to 0,852 . It meant valid.

\section{Instrument Reliability Test}

The reliability test of the instrument made use of Alfa Cronbach Standard. The reliability was attained by comparing the value of $r$ and $r$ table in the degree of $5 \%$ significance. With Alfa Cronbach Standard, $r$ was represented by Alpha value. If Alpha value was more than the value of $r$ table, it meant positive. The instrument was reliable, Santoso in Budi (2006:248). Theoretically, the calculation of reliability test was with the following formula:

$$
\begin{aligned}
& \mathrm{r}=\left(\frac{k}{k-1}\right)\left(1-\frac{k \Sigma \sigma^{2} b}{\sigma^{2} b}\right) \times 100 \% \\
& \text { Explanation: } \\
& \mathrm{r} \quad=\text { Instrument reliability coefficient } \\
& \mathrm{k} \quad=\text { Number of questions } \\
& \begin{array}{l}
\sum \sigma^{2} b=\text { Total of item variant } \\
\sigma^{2} b=\text { Total of variant. }
\end{array}
\end{aligned}
$$

Variant calculation [measurement] was conducted with the following formula:

$$
\sigma^{2}=\frac{\Sigma X^{2}-\frac{(\Sigma X)^{2}}{n}}{n-1}
$$

Explanation:

$$
\begin{array}{ll}
\sigma^{2} & =\text { The value of variant } \\
\mathrm{X} & =\text { Data values } \\
\mathrm{n} & =\text { Number of respondents }
\end{array}
$$

The degree of reliability with Alpha Cronbach technique was measured by referring to Alpha scale ranging from 0 to 1. The range was as follows:

Tabel 1. The Range for The Degree of Reliability

\begin{tabular}{|c|l|}
\hline $\begin{array}{c}\text { The Value of Alpha } \\
\text { Cronbach }\end{array}$ & \multicolumn{1}{|c|}{ The Degree of Reliability } \\
\hline $\mathbf{1}$ & \multicolumn{1}{|c|}{$\mathbf{2}$} \\
\hline $0,001-0,200$ & Less Reliable \\
$0,201-0,400$ & Somewhat Reliable \\
$0,401-0,600$ & Quite Reliable \\
$0,601-0,800$ & Reliable \\
$0,801-1,000$ & Very Reliable \\
\hline
\end{tabular}

\section{Source: Budi, 2006}

The result of instrument reliability test for enterprises performance indicated that all questions were very reliable when referred to the value of Alpha Cronbach which was 0,801 to 1,000 . The degree of reliability ranged from 0,704 to 0,726 . Meanwhile, the results of instrument reliability test for variable empowerment program implementation were from 0,676 to 0,867 which meant very reliable.

\section{Techniques of Data Analysis}

To find out how empowerment program implementation and the performance of small and medium enterprises under the Cooperative and Small and Medium Service of Ogan Ilir Regency were, the technique of analysis used was descriptive analysis technique. While to know whether there 
was any influence of empowerment program implementation towards the enterprise performance, the analysis technique applied had been explanative [confirmatory] technique by making use of simple regression approach by means of SPSS version 25 .

Before analyzing the data, there were some requirements had to do. They were data normality test, and data scale conversion from ordinal to interval.

\section{E. Data Normality Test}

The test of data normality was conducted by using sample statistical Kolmogrov Smirnov test through SPSS (Budi, 2006 : 77).

Based on One-Sample Kolmogorov-Smirnov Test, it was found that Kolmogorov-Smirnov $\mathrm{Z}$ was ,719 and the Asymp. Sig. (2-tailed) was ,679. It meant the data were normal.

Data scale conversion from ordinal to interval from 63 respondents had also be done and the results ranged from 49, 9907 to 50,0145 .

The statistical hypothesis :

Ho $: r=0 \quad$ : There was no a positive and significant effect empowerment program implementation of small and medium enterprises of in Ogan Ilir Regency towards enterprise performance

$\mathrm{H} 1: \mathrm{r} \neq 0 \quad$ : There was a positive and significant effect empowerment program implementation of small and medium enterprises of in Ogan Ilir Regency towards

Hypothesis making of correlational analysis was meant to find out the strength, the significance, and the correlational direction between the two variables.

\section{RESEARCH RESULTS}

\section{Descriptive Quantitative Analysis Technique}

Table 2. Assessment Range Score By Category Assessment Criteria Based on Average Scores of Each Indicator

\begin{tabular}{|l|l|l|}
\hline No & Score Range & Category \\
\hline 1 & $508>$ & Very Good \\
2 & $411-507$ & Good \\
3 & $314-410$ & Sufficient \\
4 & $217-313$ & Less Good \\
5 & $120-216$ & Not Good \\
\hline
\end{tabular}

\section{A. Empowerment Program Implementation}

Data analysis was carried out per indicator according to their dimensions. The following was the first indicator of the first dimension to be analyzed.

\section{Degree of Compliance}

The indicators of this first dimension were the needy documents completeness, requirement fulfillment, obedience to loan use, willingness to return loan money, and readiness to participate in the trainings offered. Each of that indicator was analyzed below.

\subsection{The Needy Documents Completeness}

In modern era, documents are extremely essential to have. They are, very often, serve as infrastructures for the next enterprise performance.

human need fulfillment. For example, one cannot apply for money loan from a bank, if one does not have, in terms of document, a personal identification card as a citizen proof. Another instance, one is not legally allowed to drive a car, if one does not possess a driving license, etc. So, are the smallmedium businesses in Ogan Ilir Regency. They could not participate in empowerment program for small-medium businesses held by Cooperative and Small-Medium Business Affairs Office of Ogan Ilir Regency, if they were not able to complete all the needy documents, like: personal identification card of Ogan Ilir Regency, family card, business licence, and home-land paid tax proof.

Regarding the ability of small-medium businesses in Ogan Ilir Regency to complete the needy documents for their participation in the empowerment program for smallmedium businesses held by Cooperative and Small-Medium Business Affairs Office of Ogan Ilir Regency, see the following table 3 .

Table 3. Respondents' Answer On The Needy Documents Completeness

\begin{tabular}{|c|c|c|c|c|c|c|c|c|c|}
\hline \multirow{2}{*}{$\begin{array}{l}\mathbf{N} \\
\mathbf{0}\end{array}$} & \multirow{2}{*}{$\begin{array}{l}\text { Stateme } \\
\text { nts }\end{array}$} & \multicolumn{5}{|c|}{ Answer options } & \multirow[t]{2}{*}{ FS } & \multirow[t]{2}{*}{$\mathbf{R S}$} & \multirow{2}{*}{$\begin{array}{l}\text { Percent } \\
\text { age }\end{array}$} \\
\hline & & $\begin{array}{l}\mathrm{VM} \\
\mathrm{D} \\
(1)\end{array}$ & \begin{tabular}{|l|}
$D$ \\
$(2$ \\
)
\end{tabular} & $\begin{array}{l}N \\
(3 \\
)\end{array}$ & $\begin{array}{l}A \\
(4 \\
)\end{array}$ & $\begin{array}{l}\text { VM } \\
\text { A } \\
(5)\end{array}$ & & & \\
\hline 1. & $\begin{array}{l}\text { There } \\
\text { are } \\
\text { some } \\
\text { docume } \\
\text { nts } \\
\text { needed. }\end{array}$ & - & - & - & 61 & 59 & $\begin{array}{l}53 \\
9\end{array}$ & $\begin{array}{l}60 \\
0\end{array}$ & $100 \%$ \\
\hline 2. & $\begin{array}{l}\text { You can } \\
\text { complet } \\
\text { e them }\end{array}$ & - & - & - & 65 & 55 & $\begin{array}{l}53 \\
5\end{array}$ & $\begin{array}{l}60 \\
0\end{array}$ & $100 \%$ \\
\hline & $\begin{array}{l}\text { Average } \\
\text { Score }\end{array}$ & & & & & & $\begin{array}{l}53 \\
7\end{array}$ & & $100 \%$ \\
\hline
\end{tabular}

Source: Questionnaires, 2018.

Annotation: Frequency Score $[\mathrm{FS}]=$ Answer option $\mathrm{x}$ score

Result Score $[\mathrm{RS}]=$ Number of Respondent $\mathrm{x} 5$

Score $=($ FS X 100\% $):$ RS

The above table indicated that all respondents, $100 \%$, were able to complete all the needed documents for the empowerment program which was held by the Cooperative and Small-Medium Business Affairs Office of Ogan Ilir Regency.

The needed documents, in general, were common ones to have for everyone. Each good citizen must have those basic papers, such as: personal identification card of Ogan Ilir Regency, family card, business licence, and home-land paid tax proof because they could also be helpful for other affairs, like enrolling children to enter schools, possessing driving licence, or getting rice ration from government for certain families. If the businesses did not have some of those documents, it was hard for them to deal with other sides for any affair. In case, the businesses had not owned some of the papers, they could right away go to the concerned offices 
to have them. Unless, did those business have those documents, they could not join the empowerment program held by Cooperative and Small-Medium Business Affairs Office of Ogan Ilir Regency. In short, the small-medium businesses had to adjust themselves with their environment in order to be successful. According to William F.Glueck and Lawrence R. Jauch [1998] - in their book entitled Strategic Management and Company Policy - that the point of strategic management that businesses always adapted themselves to environment change in order to win competition, progress, or even to be survived. Unless, would they lose their chances to develop. The business environments could be external, like government, competitor, or customer which are more demanding, or internal, for examples, tools, strategy and business policy, or the quality of available human resource.

In conclusion, that most small-medium businesses in Ogan Ilir Regency could complete all the needed documents for empowerment program. This indicator could be categorized very good because the assessment score was 537.

The second indicator of the first dimension to discuss was the ability of the small-medium businesses to fulfill the requirements applied.

\subsection{Requirement Fulfillment}

Requirement are things which are needed or wanted. In other words, it is a compulsory or necessary condition. If requirements are not met, happening will not occur. Joining the empowerment program could be realized, if the smallmedium businesses in Ogan Ilir Regency were able to fulfill the requirements applied. The requirements, among others, were; residency status, some residency documents, business documents, never got involved in the similar program, and business development plan proposal. After collecting data, whether the small-medium businesses could fulfill the conditions, the result was as follows

Table 4. Requirements Fulfillment

\begin{tabular}{|c|c|c|c|c|c|c|c|c|c|}
\hline \multirow[t]{2}{*}{ No } & \multirow{2}{*}{$\begin{array}{l}\text { Statement } \\
\text { s }\end{array}$} & \multicolumn{5}{|c|}{ Answer options } & \multirow[t]{2}{*}{ FS } & \multirow[t]{2}{*}{$\mathbf{R S}$} & \multirow{2}{*}{$\begin{array}{l}\text { Percena } \\
\text { ge }\end{array}$} \\
\hline & & $\begin{array}{l}\text { VM } \\
\text { D } \\
\text { (1) }\end{array}$ & $\begin{array}{l}\text { D } \\
(2)\end{array}$ & $\begin{array}{l}\mathbf{N} \\
\text { (3) }\end{array}$ & $\begin{array}{l}\text { A } \\
\text { (4) }\end{array}$ & $\begin{array}{l}\text { VM } \\
\text { A } \\
\text { (5) }\end{array}$ & & & \\
\hline 1. & $\begin{array}{l}\text { There are a } \\
\text { number of } \\
\text { requiremen } \\
\text { ts for the } \\
\text { empowerm } \\
\text { ent and the } \\
\text { assistance }\end{array}$ & - & - & - & 76 & 44 & 524 & 600 & $100 \%$ \\
\hline 2. & $\begin{array}{l}\text { You can } \\
\text { fulfill these } \\
\text { requiremen } \\
\text { ts }\end{array}$ & - & - & - & 68 & 52 & 532 & 600 & $100 \%$ \\
\hline & \begin{tabular}{|l|} 
Average \\
Score
\end{tabular} & & & & & & 528 & & $100 \%$ \\
\hline
\end{tabular}

Source: Questionnaires, 2018.

Annotation: Frequency Score $[\mathrm{FS}]=$ Answer option $\mathrm{x}$ score

Result Score $[\mathrm{RS}]=$ Number of Respondent $\mathrm{x} 5$

Score $=($ FS X 100\% $):$ RS
It seemed that every small-medium businesses had no problem to meet all the requirements. By percentage, it was also $100 \%$.

The Small-Medium Businesses managed hard to fulfill all the conditions and were excited to join the program. They insisted to join the program because it was very promising for their progress. The program included various aids, such as money loan for business capital, trainings, and marketing opportunities. Unless, did they take part in the program, they would have been left behind in developing their businesses. By developing themselves, small-medium businesses could play more roles in many ways, such as, making employment available, providing daily needs for the people, and contributing more revenues to government. Sudaryanto et al (2011) claimed that small-medium businesses were the biggest sector which were able to employ more labors in Indonesia and contribute better product domestic bruto through tax.

It could be concluded that each small-medium business in Ogan Ilir Regency was eligible for the empowerment program held by the Cooperative and Small-Medium Business Affairs Office of the Regency. This indicator had 528 average score which meant very good.

Next, the analysis would be continued to the third indicator of the first dimension of empowerment program implementation.

\subsection{Obedience To Loan Use}

Money lent by Local Government of Ogan Ilir Regency to the small-medium businesses in that area was supposed to use to increase business capital. The fund had to be beneficial for business development, such as buying more raw materials, tools, shop repair, business equipment, etc. The loan uses had to be obeyed as they were planned. The businesses, even, were asked to make a signed letter of agreement. Unless, were they given a punishment. To find out whether the small-medium businesses participating in the empowerment program held by the Cooperative and Small-Medium Business Affairs Office of Ogan Ilir Regency listened to the agreement, consult table below.

Table 5. Obedience To Loan Use

\begin{tabular}{|c|c|c|c|c|c|c|c|c|c|}
\hline \multirow[t]{2}{*}{ No } & \multirow{2}{*}{$\begin{array}{l}\text { Statement } \\
\text { s }\end{array}$} & \multicolumn{5}{|c|}{ Answer options } & \multirow[t]{2}{*}{ FS } & \multirow[t]{2}{*}{ RS } & \multirow{2}{*}{$\begin{array}{l}\text { Percen } \\
\text { tage }\end{array}$} \\
\hline & & \begin{tabular}{|l} 
VM \\
D \\
(1)
\end{tabular} & $\begin{array}{l}\text { D } \\
(2)\end{array}$ & $\begin{array}{l}\mathbf{N} \\
(3)\end{array}$ & $\begin{array}{l}\text { A } \\
\text { (4) }\end{array}$ & $\begin{array}{l}\text { VM } \\
\text { A } \\
\text { (5) }\end{array}$ & & & \\
\hline 1. & $\begin{array}{l}\text { You use } \\
\text { loan } \\
\text { money } \\
\text { according } \\
\text { to the } \\
\text { stipulated } \\
\text { conditions }\end{array}$ & 15 & 5 & 30 & 43 & 27 & 422 & 600 & $58.3 \%$ \\
\hline & $\begin{array}{l}\text { Average } \\
\text { Score }\end{array}$ & & & & & & 422 & & $58.3 \%$ \\
\hline
\end{tabular}

Source: Questionnaires, 2018.

Annotation: Frequency Score $[\mathrm{FS}]=$ Answer option $\mathrm{x}$ score

Result Score $[\mathrm{RS}]=$

Number of Respondent x 5

Score $=($ FS X 100\% $):$ RS 
Data in table 5 above showed that the agreeing answers to the appropriate loan use dominated the response. The total percentage was $58.3 \%$. It could be understood that most respondents used the loan money for their business capital since the main purpose of borrowing the money was to increase business capital. The loan money was utilized to buy tools, more raw materials, improve business place, and equipments.

While, the respondents who abused the loan money manipulated it for something else, such as, for daily needs, school fee, and others. The reasons they abused the money were that, firstly, they had to fulfill they daily needs. In addition, some said they needed to buy their seconder necessities which they had long dreamed of, like colourful TV set, a better bed set, fridge. They could not pay for them for they had no money. When they had that loan money on hand, they carried out their desires. Secondly, they found low demand for goods in market place. They thought it was no use to get more wares which finally was unsellable that they satisfied themselves with the items they actually required.

It was proved that although some respondents disobeyed the appropriate use of the loan money. Anyhow, most of them did the right things by using the loan money appropriately. Maman Rachman in Tu'u (2004: 35) stated that discipline or obedience is very important for each individual, such as; (1) provide support for the creation of non-deviant behavior; (2) to regulate the balance of the desires of one individual with another; and (3) good habits cause peace of mind and environment.

Regarding the obedience to loan use, it could be said that there was conformity to it. The loan money was used correctly by most of respondents for business capital increase. The average score for this indicator was 422 . It was classified good.

The fourth indicator of the first dimension was willingness to return the loan money.

\subsection{Willingness To Return Loan Money}

Loan or also called credit is the trust of the borrower to pay a sum of money in the future (Rolling G. Thomas, 1957: 109). Referring to the above understanding that indeed something borrowed in its essence must be returned. The Ogan Ilir Cooperative Office did not merely provide useless assistance, but the money that had been lent to each related small-medium business [SMB] must be returned to the capital provider, Cooperative and Small-Medium Business Affairs Office of Ogan Ilir Regency. The following table will inform you the answers to the questionnaire from the respondents regarding the above matter.

Table 6. Willingness To Return Loan Money

\begin{tabular}{|c|c|c|c|c|c|c|c|c|c|}
\hline \multirow[t]{2}{*}{ No } & \multirow{2}{*}{$\begin{array}{l}\text { Statemen } \\
\text { ts }\end{array}$} & \multicolumn{5}{|c|}{ Answer options } & \multirow[t]{2}{*}{ FS } & \multirow[t]{2}{*}{ RS } & \multirow{2}{*}{$\begin{array}{l}\text { Percenta } \\
\text { ge }\end{array}$} \\
\hline & & $\begin{array}{l}\text { VM } \\
\text { D } \\
\text { (1) }\end{array}$ & $\begin{array}{l}\mathrm{D} \\
\text { (2) }\end{array}$ & $\begin{array}{l}\mathbf{N} \\
\text { (3) }\end{array}$ & $\begin{array}{l}A \\
\text { (4) }\end{array}$ & $\begin{array}{l}\text { VM } \\
\text { A } \\
(\mathbf{5})\end{array}$ & & & \\
\hline 1. & $\begin{array}{l}\text { You } \\
\text { return the } \\
\text { loan to } \\
\text { the } \\
\text { borrower }\end{array}$ & 13 & 15 & 26 & 39 & 27 & 412 & 600 & $55 \%$ \\
\hline & $\begin{array}{l}\text { Average } \\
\text { Score }\end{array}$ & & & & & & 412 & & $55 \%$ \\
\hline
\end{tabular}

Source: Questionnaires, 2018.
Annotation: $\quad$ Frequency Score $[F S]=$ Answer option $x$ score

Result Score $[\mathrm{RS}]=$ Number of Respondent $\times 5$

Score $=($ FS X 100\% $):$ RS

From 120 SMBs which were lent the money for business capital, 66 of them said that they willingly returned the borrowed money. They did it since their businesses were profitable and well developed. They were committed. It was an obligation for them as the agreement.

Nevertheless, some $45 \%$ of the respondents did not returned the loan. Some of their reasons were their loss in business, gambling use, and others. This was not bad, both for the businesses and the local government, since the fund which should have been returned on a rolling basis could not been used to help other businesses. It was contrary to the theory presented by Thomas Suyatno (2007: 130) which stated that credit or debt is the provision of money equalized bills that are in accordance with agreement between the borrower and the lender.

The discussion above gave information that $55 \%$ of respondents were committed to return the loan money. This indicator, willingness to return loan money, was scored 412. It was classified sufficient

The last indicator which would be discussed from the dimensions of degree of compliance was acceptance of training.

\subsection{Readiness To Participate In The Trainings Offered}

Training is a variety of introductory efforts to develop workforce performance in the work carried out or also something related to his work (Bernardin \& Russell, 1998: 172). This means changing specific and specific behaviors, attitudes, skills and knowledge. Training in the business world or business becomes important and cannot be underestimated, because the training itself is useful for improving skills, which later when the skills are increased it will also increase business productivity. There are various types of training in the business world, and the most common are training on business management, business technical training, marketing training, and packaging training. Nitisemito (1996: 35) defines that training is an activity that intends to improve and develop the attitudes, behavior, skills and knowledge of individuals who are given training.

Relating to training for small-medium businesses, the Cooperative and Small-Medium Business Affairs Office of Ogan Ilir Regency. The four types of training available for the empowered small-medium businesses in Ogan Ilir Regency were management business, business technical, marketing, and packaging.

The following was the perception of respondents regarding the above matters. 
Table 7. Readiness To Participate In The Trainings Offered

\begin{tabular}{|c|c|c|c|c|c|c|c|c|c|}
\hline \multirow[b]{2}{*}{ No } & \multirow{2}{*}{$\begin{array}{l}\text { Statement } \\
\text { s }\end{array}$} & \multicolumn{5}{|c|}{ Answer options } & \multirow[t]{2}{*}{ FS } & \multirow[t]{2}{*}{$\mathbf{R S}$} & \multirow{2}{*}{$\begin{array}{l}\text { Percenta } \\
\text { ge }\end{array}$} \\
\hline & & \begin{tabular}{|l|}
$V M$ \\
$D$ \\
$(1)$
\end{tabular} & $\begin{array}{l}\text { D } \\
\text { (2) }\end{array}$ & $\begin{array}{l}\mathbf{N} \\
(3)\end{array}$ & $\begin{array}{l}\text { A } \\
\text { (4) }\end{array}$ & $\begin{array}{l}\text { VM } \\
\text { A } \\
(\mathbf{5})\end{array}$ & & & \\
\hline 1. & $\begin{array}{l}\text { You are } \\
\text { given } \\
\text { training on } \\
\text { business } \\
\text { manageme } \\
\text { nt by the } \\
\text { Cooperati } \\
\text { ve Office }\end{array}$ & 19 & 6 & 4 & 56 & 35 & 442 & 600 & $75,83 \%$ \\
\hline 2 & $\begin{array}{l}\text { You are } \\
\text { given } \\
\text { technical } \\
\text { business } \\
\text { training }\end{array}$ & 23 & 3 & - & 52 & 42 & 447 & 600 & $78,3 \%$ \\
\hline 3 & $\begin{array}{l}\text { You are } \\
\text { given } \\
\text { marketing } \\
\text { training }\end{array}$ & 25 & 2 & - & 48 & 45 & 446 & 600 & $77,5 \%$ \\
\hline 4 & $\begin{array}{l}\text { You are } \\
\text { given } \\
\text { packaging } \\
\text { training }\end{array}$ & 21 & 3 & 1 & 50 & 45 & 455 & 600 & $79,16 \%$ \\
\hline 5 & $\begin{array}{l}\text { You } \\
\text { attended } \\
\text { all the } \\
\text { trainings } \\
\text { provided }\end{array}$ & 11 & 7 & 2 & 58 & 42 & 473 & 600 & $83,33 \%$ \\
\hline & \begin{tabular}{|l}
$\begin{array}{l}\text { Average } \\
\text { Score }\end{array}$ \\
\end{tabular} & & & & & & 453 & & $78,82 \%$ \\
\hline
\end{tabular}

Source: Questionnaires, 2018.

Annotation: Frequency Score $[\mathrm{FS}]=$ Answer option $\mathrm{x}$ score

Result Score $[\mathrm{RS}]=$ Number of Respondent $\times 5$

Score $=($ FS X 100\% $):$ RS

Looking at the data in Table above, it showed that $78,82 \%$ of respondents said they received training provided by the Ogan Ilir Cooperative Service based. Participating in training is indeed important for certain individuals, especially business people, because it has certain goals for the individual concerned. Procton and Thornton (1983: 4) mention the training objectives are; (1) to adjust to the demands of business and industrial operations since the first day of work; and (2) making progress as a productive force in the company by developing the needs of skills, knowledge and attitudes. In accordance with Procton and Thornton, the empowered small-medium businesses in Ogan Ilir Regency got some benefits from trainings attended. Namely, better culinary skill, business management, marketing knowledge, and work-relating to packaging. They, even, got also some knowledge from other participants when they had discussions in their togetherness. If not, the trainings would have been left behind for wasting time.

Another $21,18 \%$ admitted they did not take part in the trainings available because they had some reasons. They were: they thought they had already been good at making specific preferred local food they sold, some said they had no one looking after their businesses if they went for the trainings, and few reasoned that they did not gain a clear information on the trainings.

Amongs others, the point was that the average score of the indicator of readiness to participate in the trainings offered was classified good. It was 453 .

Having analyzed each indicator of the degree of compliance, the first dimension, it could be concluded that most small-medium businesses empowered by the Cooperative and Small-Medium Business Affairs Office of Ogan Ilir Regency complied the conditions of empowerment program. The degree of compliance was high. It was indicated by the following proofs;

1. All small-medium businesses were able to complete the needed documents. The score was 537 which mean very good.

2. None of the businesses could not fulfill the requirement. It was classified very good as well since the score was 528 .

3. Most businesses - 58,30\% - used the loan money as should be. It was scored Good, 422 .

4. $55 \%$ of respondents succeeded to return the loan. The classification score was 412 which meant sufficient.

5. Majority of the businessmen took part in training available. It was scored 453 and was good.

After analyzing the first dimension, it was followed by the second one, the smoothness of routine functions.

\section{Implementation Smoothness of Routine Functions}

There were 2 indicators included in this second dimension. They were production process smoothness as well as product and service marketing smoothness. The analysis would be carried out one after another.

\subsection{Production Process Smoothness}

Raw material is something that is used to make finished goods. Materials must stick to become one with finished goods (Hanggana, 2006: 11). Raw materials are the most important component in every business sector. In production process, one of the valuable elements is raw material. It should be available in right amount, good quality, and in time arrival. Unless, the production process will be stagnant.

The small-medium businesses in Ogan Ilir Regency had received loan for business capital. Therefore, it was reasonable if they could have more and better raw materials for their business productions. Concerning production process smoothness in their business, when they were asked, the small-medium businesses under the empowerment of the Cooperative and Small-Medium Business Affairs Office of Ogan Ilir Regency answered as follows. 
Table 8. Production Process Smoothness

\begin{tabular}{|l|l|l|l|l|l|l|l|l|l|}
\hline No & $\begin{array}{l}\text { Statemen } \\
\text { ts }\end{array}$ & $\begin{array}{l}\text { VM } \\
\mathbf{D} \\
\mathbf{( 1 )}\end{array}$ & $\begin{array}{l}\mathbf{D} \\
\mathbf{( 2 )}\end{array}$ & $\begin{array}{l}\mathbf{N} \\
\mathbf{( 3 )}\end{array}$ & $\begin{array}{l}\mathbf{A} \\
\mathbf{( 4 )}\end{array}$ & $\begin{array}{l}\text { VM } \\
\mathbf{A} \\
\mathbf{( 5 )}\end{array}$ & FS & RS & $\begin{array}{l}\text { Percenta } \\
\text { ge }\end{array}$ \\
\hline 1. & $\begin{array}{l}\text { The } \\
\text { process } \\
\text { of your } \\
\text { business } \\
\text { productio } \\
\text { n is } \\
\text { smooth }\end{array}$ & 1 & 17 & 14 & 64 & 24 & 453 & 600 & $73.3 \%$ \\
\hline & $\begin{array}{l}\text { Average } \\
\text { Score }\end{array}$ & & & & & & $\mathbf{4 5 3}$ & & $\mathbf{7 3 . 3 \%}$ \\
\hline
\end{tabular}

Source: Questionnaires, 2018.

Annotation: Frequency Score $[\mathrm{FS}]=$ Answer option $\mathrm{x}$ score

Result Score $[\mathrm{RS}]=$ Number of Respondent $\times 5$

Score $=($ FS X 100\% $):$ RS

Referring to the data in table above, it was known that majority - 88 businesses - of respondents found that their process production smooth. One of the causes was the fulfillment of business raw materials got hardly any problem. The smoothness happened due to good procurement and - of course - payment. Here lay the role of the loan money for business capital. Unless was business capital available, business raw material procurement could be an obstacle. This was in line with the opinion of Assauri (2004: 177) who said that supply control was useful for; (1) keep the company from running out of supplies so that production activities can be stopped; (2) keep the formation of company inventories not too large or excessive; and (3) keeping small purchases can be avoided because the ordering costs will be too large.

Since the average score of production process smoothness was 453 . It could be grouped into good category.

The final indicator of the second dimension, the smoothness of routine functions, which would be analyzed was would be product and service marketing smoothness.

\subsection{Product And Service Marketing Smoothness}

Dr. Philip Kotler - https://heidicohen.com/marketingdefinition - defines marketing as "the science and art of exploring, creating, and delivering value to satisfy the needs of a target market at a profit. Marketing identifies unfulfilled needs and desires. It defines, measures and quantifies the size of the identified market and the profit potential. It pinpoints which segments the company is capable of serving best and it designs and promotes the appropriate products and services." In short, the capacity of a producer to satisfy customers through product or service delivered has been marketing. Small-medium businesses empowered by the Cooperative and Small-Medium Business Affairs Office of Ogan Ilir Regency produced diverse products and services. The description whether they could market their products and services smoothly, see the below table.
Table 9. Product And Service Marketing Smoothness

\begin{tabular}{|c|c|c|c|c|c|c|c|c|c|}
\hline \multirow[b]{2}{*}{$\begin{array}{l}\mathbf{N} \\
\mathbf{0}\end{array}$} & \multirow[b]{2}{*}{$\begin{array}{c}\text { Statemen } \\
\text { ts }\end{array}$} & \multicolumn{5}{|c|}{ Answer options } & \multirow[b]{2}{*}{ FS } & \multirow[b]{2}{*}{$\mathbf{R S}$} & \multirow[b]{2}{*}{$\begin{array}{l}\text { Perce } \\
\text { ntage }\end{array}$} \\
\hline & & $\begin{array}{c}\text { VMD } \\
\text { (1) }\end{array}$ & \begin{tabular}{|l|} 
D \\
$(2)$
\end{tabular} & $\begin{array}{l}\mathbf{N} \\
(3)\end{array}$ & $\begin{array}{l}A \\
(4)\end{array}$ & $\begin{array}{c}\text { VMA } \\
\text { (5) }\end{array}$ & & & \\
\hline . & \begin{tabular}{|c} 
Your \\
product \\
or service \\
were \\
marketabl \\
$\mathrm{e}$
\end{tabular} & 19 & 24 & 13 & 45 & 19 & 381 & 600 & $\begin{array}{c}53.33 \\
\%\end{array}$ \\
\hline 2. & $\begin{array}{c}\text { You } \\
\text { could } \\
\text { market } \\
\text { them } \\
\text { smoothly }\end{array}$ & - & 36 & 18 & 58 & 8 & 398 & 600 & $55 \%$ \\
\hline & $\begin{array}{c}\text { Average } \\
\text { Score }\end{array}$ & & & & & & 389 & & $\begin{array}{c}\mathbf{5 4 , 1 6} \\
\%\end{array}$ \\
\hline
\end{tabular}

Source: Questionnaires, 2018.

Annotation: Frequency Score $[\mathrm{FS}]=$ Answer option $\mathrm{x}$ score

Result Score $[\mathrm{RS}]=$ Number of Respondent x 5

Score $=($ FS X 100\% $):$ RS

Table above informed us that - on average - 54\% respondents stated that the products or services they produced could be marketed smoothly. Continuous product supply played an essential role in marketing. If production was hampered, marketing could also be hung up. The smooth and unhindered production process was needed in business activities, because -according to Ahyari (2002: 211) it was [the production process] was intermittent, if there was no exact sequence or pattern from raw material to final product or order is always changing. Therefore, it was determined by stable raw material supply. In this context, capital to buy raw materials was a determinant factor. Successful marketing gave much contribution to income. In https://www.salesfusion.com/resource/measuring-

marketing-effectiveness-5-metrics-need-track, it was stated that effective marketing had 5 parameters. They were marketing contribution to revenue, pipeline growth and acceleration, conversion rates:, cost per lead, cost per opportunity, and brand awareness.

Although most respondent found that they got successful in product or service marketing, but some of them experienced fluctuative situation. Even though, it was not very encouraging, but it was positive. The average score was 389 , it was, then, included to sufficient.

In general, in terms of routine functions, it could be stated that it could run smoothly. The reasons were majority -88 businesses - of respondents found that their process production smooth. The average score of production process smoothness was 453. It could be grouped into good category. In addition, 54\% respondents stated that the products or services they produced could be marketed smoothly. The average score was 389 , it was, then, included to sufficient.

The last dimension of variable empowerment program implementation was the impact of the program implementation 


\section{The Impact of Empowerment Program Implementation}

This dimension had 2 indicators. Namely; more and broader product and service marketing and better welfare. They were analyzed as follows.

\subsection{More and broader product and service marketing}

Marketing is one form of human activity that has a foundation for getting needs and desires through a series of processes of exchange, supply, and many other things (Kotler, 2001: 10). Marketing is one of the most important stages in every field of business, and marketing can also be done in a variety of ways, both marketing directly or indirectly such as advertising or brochures. Marketing product and service should be smooth, continuous, and more as well as broader in covering the area.

One of the purposes of empowerment program implementation for small-medium business in Ogan Ilir Regency was keeping the businesses' product and service marketing run well and got more and broader. In accordance with this, respondents' answer on question whether their product and service marketing become more and broader in area coverage, the result was as follows.

Table 10. More and Broader Product and Service Marketing

\begin{tabular}{|c|c|c|c|c|c|c|c|c|c|}
\hline \multirow[b]{2}{*}{ No } & \multirow[b]{2}{*}{ Statements } & \multicolumn{5}{|c|}{ Answer options } & \multirow[b]{2}{*}{ FS } & \multirow[b]{2}{*}{$\mathbf{R S}$} & \multirow[b]{2}{*}{$\begin{array}{l}\text { Percen } \\
\text { tage }\end{array}$} \\
\hline & & $\begin{array}{l}\text { VM } \\
\text { D } \\
(1)\end{array}$ & $\begin{array}{l}D \\
(2)\end{array}$ & $\begin{array}{l}\mathbf{N} \\
\text { (3) }\end{array}$ & $\begin{array}{l}A \\
(4)\end{array}$ & $\begin{array}{l}\text { VM } \\
\text { A } \\
(\mathbf{5})\end{array}$ & & & \\
\hline 1. & $\begin{array}{l}\text { Your } \\
\text { product and } \\
\text { service } \\
\text { marketing } \\
\text { became } \\
\text { more and } \\
\text { covered } \\
\text { broader } \\
\text { area, partly, } \\
\text { as the result } \\
\text { of your } \\
\text { participatio } \\
\text { n in the } \\
\text { empowerme } \\
\text { nt program. }\end{array}$ & 2 & 29 & 27 & 50 & 12 & 401 & 600 & $\begin{array}{l}51.67 \\
\%\end{array}$ \\
\hline & \begin{tabular}{|l} 
Average \\
Score
\end{tabular} & & & & & & 401 & & $\begin{array}{l}51.67 \\
\%\end{array}$ \\
\hline
\end{tabular}

Source :Questionnaires, 2018.

Annotation: Frequency Score $[\mathrm{FS}]=$ Answer option $\mathrm{x}$ score

Result Score $[\mathrm{RS}]=$ Number of Respondent $\times 5$

Score $=($ FS X 100\% $):$ RS

Table above indicated that from 120 respondents, 62 of them agreed and very much agreed [answered true and very true] that they could market more product and service and covered wider area.

This likable achievement happened because the empowerment program gave trainings for better skill, lent money for business capital, and helped marketing the products and services produced through yearly scheduled exhibition held by local and provincial governments, stateowned enterprises, other expositions or festivals, both the scheduled and the sudden one. Without this empowerment, it was quite impossible for the businesses to develop themselves in short time for their very limited capacity. It was in line with the opinion of Kotler (2005: 11) on the concept of marketing also stated that the key to achieving organizational goals was to be more effective than competitors in integrating marketing activities to determine and satisfy the needs of the target market.

It could be deduced $51,6 \%$ respondents could market more product and service and covered wider area. By classification, this indicator was categorized sufficient, since the average score was 401 .

The analysis will be continued to the second indicator better welfare - of the last dimension of variable empowerment program implementation.

\subsection{Better Welfare}

Welfare - for some people - has been the basic purpose of running a business. All efforts taken are directed to accomplish this goal. So, are the small-medium businesses empowered by the Cooperative and Small-Medium Business Affairs Office of Ogan Ilir Regency. When the business were asked - as respondents of this research - on their welfare due to their business progress, their answers were like in table below.

Table 11 Better Welfare

\begin{tabular}{|c|c|c|c|c|c|c|c|c|c|}
\hline \multirow[b]{2}{*}{ No } & \multirow[b]{2}{*}{$\begin{array}{l}\text { State } \\
\text { ments }\end{array}$} & \multicolumn{5}{|c|}{ Answer options } & \multirow[b]{2}{*}{$\mathbf{S}^{\mathbf{F}}$} & \multirow[b]{2}{*}{$S^{R}$} & \multirow[b]{2}{*}{$\begin{array}{l}\text { Perce } \\
\text { ntage }\end{array}$} \\
\hline & & $\begin{array}{l}\mathrm{V} \\
\mathrm{MD} \\
(1)\end{array}$ & $\begin{array}{l}D \\
(2)\end{array}$ & $\begin{array}{l}\mathbf{N} \\
(\mathbf{3})\end{array}$ & \begin{tabular}{|l} 
A \\
$\mathbf{( 4 )}$
\end{tabular} & $\begin{array}{r}\text { V } \\
\text { MA } \\
\text { (5) }\end{array}$ & & & \\
\hline 1. & \begin{tabular}{l}
\multicolumn{1}{c}{ Your } \\
welfare \\
has been \\
better \\
due to \\
your \\
business \\
progress
\end{tabular} & 2 & 36 & 10 & 58 & 14 & $06^{4}$ & $00^{6}$ & $60 \%$ \\
\hline & $\begin{array}{r}\text { Avera } \\
\text { ge Score }\end{array}$ & & & & & & $0^{4}$ & & $60 \%$ \\
\hline
\end{tabular}

Source: Questionnaires, 2018.

Annotation: Frequency Score $[\mathrm{FS}]=$ Answer option $\mathrm{x}$ score

Result Score $[\mathrm{RS}]=$ Number of Respondent x 5

Score $=($ FS X 100\% $):$ RS

There were 72 out of 120 respondents who admitted that their welfare had been better due to their business development.

Logically, if a business had been well managed, sooner or later, it would head to an enhancement. The enhancement occurred because business capital became more. With better finance, more raw materials, tools, and other businessrelated necessities could be fulfilled. Those businessmen had also be trained for better competencies. Through this betterment, the product, the service, and the process got better and more efficient.

These all led to more products and services sellable. The more selling well, the more profitable the business 
was. This condition supported welfare gain for the businessmen.

The discussion above led to conclusion that $60 \%$ of the small-medium business had a better welfare since they were empowered by the Cooperative and Small-Medium Business Affairs Office of Ogan Ilir Regency. In terms of the average score, it was 406 and classified into sufficient.

It could be deduced $51,6 \%$ respondents could market more product and service and covered wider area. By classification, this indicator was categorized sufficient, since the average score was 401. There were 72 out of 120 respondents who admitted that their welfare had been better due to their business development. In terms of the average score, it was 406 and classified into sufficient.

The finding from the analysis of each indicator of every dimension of variable empowerment program implementation denoted that empowerment program implementation was successful. It was notified from the facts that the degree of compliance was scored 458 which meant good.

Here is the end of the descriptive statistics [Descriptive Quantitative] analysis of variable Empowerment Program Implementation [variable $\mathrm{X}$ ]. The next is the analysis of variable Y, Namely The Performance Of Small and Medium Businesses Which Were Fostered By The Cooperative and Small And Medium Office Of Ogan Ilir Regency.

\section{B. The Performance Of Small and Medium Businesses}

This variable has 4 dimensions, namely, Finance, Customer, Internal Process, and Growth and Learning.

The financial dimension has 2 indicators. While the customer dimension consists of 2 indicators. Furthermore, for the internal process dimension, there are 3 indicators, and the dimension of growth and learning owns 4 indicators.

The analysis will be carried out per indicator for each dimension and will be begun with the first indicator from the first dimension.

\section{Finance}

The financial dimension has 2 indicators, namely 1) Business Capital Returns, 2) Business profits.

\subsection{Return on business capital}

Timeliness of loan Payback is also very important. It is to increase the confidence of financiers (Office of Cooperative Ogan Ilir Regency) to the capital beneficiaries. Here will be presented the answers to questionnaires from respondents regarding the above.

Table 12. Return on business capital

\begin{tabular}{|l|l|l|l|l|l|l|l|l|l|}
\hline \multirow{2}{*}{ No } & $\begin{array}{l}\text { Statemen } \\
\text { ts }\end{array}$ & $\begin{array}{l}\text { Answer options } \\
\text { VM } \\
\mathbf{D} \\
\mathbf{( 1 )}\end{array}$ & $\begin{array}{l}\mathbf{D} \\
\mathbf{( 2 )}\end{array}$ & $\begin{array}{l}\mathbf{N} \\
\mathbf{( 3 )}\end{array}$ & $\begin{array}{l}\mathbf{A} \\
\mathbf{( 4 )}\end{array}$ & $\begin{array}{l}\text { VM } \\
\mathbf{A} \\
\mathbf{( 5 )}\end{array}$ & FS & RS & $\begin{array}{l}\text { Percenta } \\
\text { ge }\end{array}$ \\
\hline 1. & $\begin{array}{l}\text { You } \\
\text { return the } \\
\text { loaned } \\
\text { capital on } \\
\text { time }\end{array}$ & 20 & 6 & 23 & 42 & 29 & 414 & 600 & $59.16 \%$ \\
\hline & $\begin{array}{l}\text { Average } \\
\text { Score }\end{array}$ & & & & & & $\mathbf{4 1 4}$ & & $\mathbf{5 9 . 1 6 \%}$ \\
\hline
\end{tabular}

Source: Questionnaires, 2018.

Annotation: Frequency Score $[\mathrm{FS}]=$ Answer option $\mathrm{x}$ score
Result Score $[\mathrm{RS}]=$ Number of Respondent $\mathrm{x} 5$

Score $=($ FS X 100\% $):$ RS

Looking at the data in the table above, it showed that most of the respondents returned business capital loans on time. This could be seen from $59.16 \%$ of respondents answering agree. This meaned that the managed business was successful and gave benefits. From these benefits, they used to expand their business and paid capital loans on time to the Ogan Ilir Regency Cooperative Office.

It could be deduced 71 respondents returned business capital lent on time with an average total score of 414 . The score was included in the good category.

Next, the second indicator of the financial dimension would be discussed was business profits.

\subsection{Business Profit}

Profit is one of the main goals of business people in carrying out their activities. The profit earned will be used for various purposes, the profit will also increase the welfare of business actors for the services or products they provide. profit is the overall measure of a company's achievement defined as follows: Profit $=$ Sales - Cost (Hanafi, 2010: 32) . The following was the respondents' questionnaire answers regarding the above matters.

Table 13. Business benefits

\begin{tabular}{|c|c|c|c|c|c|c|c|c|c|}
\hline \multirow[b]{2}{*}{ No } & \multirow[b]{2}{*}{$\begin{array}{l}\text { Statemen } \\
\text { ts }\end{array}$} & \multicolumn{5}{|c|}{ Answer options } & \multirow[b]{2}{*}{ FS } & \multirow[b]{2}{*}{$\mathbf{R S}$} & \multirow[b]{2}{*}{$\begin{array}{l}\text { Percenta } \\
\text { ge }\end{array}$} \\
\hline & & $\begin{array}{l}\text { VM } \\
\text { D } \\
\text { (1) }\end{array}$ & $\begin{array}{l}\text { D } \\
(2)\end{array}$ & $\begin{array}{l}\mathbf{N} \\
(3)\end{array}$ & $\begin{array}{l}\text { A } \\
(4)\end{array}$ & \begin{tabular}{|l}
$\mathbf{V M}$ \\
$\mathbf{A}$ \\
$\mathbf{( 5 )}$
\end{tabular} & & & \\
\hline 1. & $\begin{array}{l}\text { You } \\
\text { benefit } \\
\text { from the } \\
\text { business }\end{array}$ & - & - & - & 93 & 17 & 480 & 600 & $91,67 \%$ \\
\hline 2. & $\begin{array}{l}\text { The } \\
\text { benefits } \\
\text { of your } \\
\text { business } \\
\text { increase }\end{array}$ & 2 & 24 & 22 & 66 & 6 & 410 & 600 & $60 \%$ \\
\hline & $\begin{array}{l}\text { Average } \\
\text { Score }\end{array}$ & & & & & & 445 & & $75,83 \%$ \\
\hline
\end{tabular}

Source: Questionnaires, 2018.

Annotation: Frequency Score $[\mathrm{FS}]=$ Answer option $\mathrm{x}$ score

Result Score $[\mathrm{RS}]=$ Number of Respondent $\mathrm{x} 5$

Score $=($ FS X 100\% $):$ RS

Based on the table above, it showed that all respondents stated that they benefited from the business they lived in. These benefits were used to increase their business so that the profits obtained were even greater. Profit was indeed very important for business continuity for the foreseeable future, because of the profits obtained, business actors would balance certain expenditure costs, as stated by $\mathrm{M}$. Nafarin (2007: 788) that profit was the difference between income and the balance of costs and expenditure for a certain period.

Since the average score of business profit was 445. It 
could be grouped into good category.

Overall, in terms of finance, it was declared good. The reason was in capital lending, as many as 71 respondents returned capital on time with an average score of 414 in the good category. Then, an indicator of business profits, as many as 72 respondents stated that they received profits from the business they lived in with an average score of 445 . The score was included in the good category.

Next, the second dimension will be discussed, namely the customer with the first indicator is the customer group.

\section{Customer}

\subsection{Customer group}

Customers are those who buy or use products or services from a company. Customers of a product must be developed and expanded to make business products known and known. That is why customers must be sought through intense marketing.

Greenberg (2010: 116) stated that customers were individuals or groups who bought physical products or services by considering various factors such as price, quality, place, service and so on based on their own decisions. The respondents' questionnaire answers regarding the above matters were as follows.

Table 14. Customer group

\begin{tabular}{|l|l|l|l|l|l|l|l|l|l|}
\hline \multirow{2}{*}{ No } & $\begin{array}{l}\text { Statemen } \\
\text { ts }\end{array}$ & $\begin{array}{l}\text { Answer options } \\
\text { VM } \\
\mathbf{D}\end{array}$ & $\begin{array}{l}\mathbf{D} \\
\mathbf{( 2 )}\end{array}$ & $\begin{array}{l}\mathbf{N} \\
\mathbf{( 3 )}\end{array}$ & $\begin{array}{l}\mathbf{A} \\
\mathbf{( 4 )}\end{array}$ & $\begin{array}{l}\text { VM } \\
\mathbf{A} \\
\mathbf{( 5 )}\end{array}$ & FS & RS & $\begin{array}{l}\text { Percenta } \\
\text { ge }\end{array}$ \\
\hline 1. & $\begin{array}{l}\text { You get } \\
\text { new } \\
\text { customers }\end{array}$ & 5 & 19 & 20 & 58 & 18 & 425 & 600 & $63,33 \%$ \\
\hline & $\begin{array}{l}\text { Average } \\
\text { Score }\end{array}$ & & & & & & $\mathbf{4 2 5}$ & & $\mathbf{6 3 , 3 3 \%}$ \\
\hline
\end{tabular}

Source :Questionnaires, 2018.

Annotation: $\quad$ Frequency Score $[F S]=$ Answer option $x$ score

Result Score $[R S]=$ Number of Respondent $x 5$

Score $=($ FS X 100\% $):$ RS

The Table above showed that most of the respondents stated that they got new customers. It was seen from $63.33 \%$ of respondents answering agree. Customers or new consumers of a business product must be given satisfaction, because if the new customers were satisfied with the product, or the services provided, it was possible that they would be loyal to the related business product.

Surianto and Aisya (2009: 170) argued that if the customer was satisfied, it could provide benefits for the company in the form of a greater shopperan and the possibility of becoming a customer in the long run.

The statement of respondents regarding the above questionnaire had a score of 425 , which was included in the good category. The next indicator from the customer dimension was customer mobility.

\subsection{Customer mobility}

New customers are good for a business, in order to make the business more known and developed. However, the most important thing is to make existing customers continue to use business products rather than looking for new customers, because customers who are interested in the product and service will be very easily influenced to conduct repeat transactions. The following were the respondents' questionnaire answers regarding the above matters.

Table 15. Customer mobility

\begin{tabular}{|l|l|l|l|l|l|l|l|l|l|}
\hline No & $\begin{array}{l}\text { Statemen } \\
\text { ts }\end{array}$ & $\begin{array}{l}\text { Answer options } \\
\text { VM } \\
\mathbf{D} \\
\mathbf{( 1 )}\end{array}$ & $\begin{array}{l}\mathbf{D} \\
\mathbf{( 2 )}\end{array}$ & $\begin{array}{l}\mathbf{N} \\
\mathbf{( 3 )}\end{array}$ & $\begin{array}{l}\mathbf{A} \\
\mathbf{( 4 )}\end{array}$ & $\begin{array}{l}\text { VM } \\
\mathbf{A} \\
\mathbf{( 5 )}\end{array}$ & FS & RS & $\begin{array}{l}\text { Percenta } \\
\text { ge }\end{array}$ \\
\hline 1. & $\begin{array}{l}\text { Your old } \\
\text { customers } \\
\text { remain } \\
\text { loyal }\end{array}$ & 3 & 17 & 15 & 66 & 19 & 441 & 600 & $70.83 \%$ \\
\hline & $\begin{array}{l}\text { Average } \\
\text { Score }\end{array}$ & & & & & & $\mathbf{4 4 1}$ & & $\mathbf{7 0 . 8 3 \%}$ \\
\hline
\end{tabular}

Source: Questionnaires, 2018.

Annotation: Frequency Score $[\mathrm{FS}]=$ Answer option $\mathrm{x}$ score

Result Score $[R S]=$ Number of Respondent $x 5$

Score $=($ FS X 100\%): RS

Based on the data in the table above, in this statement the most dominant answer from respondents - 70,83\%- were to agree. Regarding customers' loyality, Griffin, (2003: 31), loyal or loyal customers are very useful for every business, while the loyal customers are, among others; (1) make repeated purchases regularly; (2) buy between product lines and services; (3) referring to others; and (4) show immunity to attraction from competitors

The respondent's statement regarding the questionnaire above had a score of 441 , which belonged to the good category.

So, the conclusion of the two indicators on the second dimension of the $\mathrm{Y}$ variable is that there are 76 respondents from 120 respondents stating that they did get new customers, and there were 85 respondents from 120 respondents who stated their old customers remained loyal. The percentage of respondents from the first indicator of the second dimension of variable $\mathrm{Y}$ who said that indeed they got new customers was $63.33 \%$. While the percentage of the second indicator that said their old customers remained loyal was $70.83 \%$. The sum of the percentage of the first indicator and the second indicator of the $\mathrm{Y}$ variable is divided by 2 , That is $(63.33+70.83): 2=67.08$. So the percentage of the second dimension of the $\mathrm{Y}$ variable, namely the Quality dimension is $67.08 \%$.

The third dimension which will be discussed is the internal process. The first indicator will be the bookkeeping.

\section{Internal Process}

\subsection{Book-keeping System}

Book-keeping is the act of recording financial transactions. Transactions include sales, purchases, income and expenses by individuals and organizations.

Whereas according to Law No. 28 of 2007 Article 28 book-keeping is defined as a process of recording that must be carried out regularly to collect financial data and information including assets, liabilities, capital, income, 
and costs, as well as the acquisition price and delivery of goods or services, which are closed by preparing financial statements in the form of balance sheet and income statement for a certain period. Accounting is used almost in every activity or business, this is useful for recapitulation of data at any time needed, especially in the world of economy or book-keeping business is very mandatory to see the estimated funds to be issued or funds that will enter. The following was the respondents' to questionnaire answers regarding the above matters.

Table 16. The Book-keeping System

\begin{tabular}{|c|c|c|c|c|c|c|c|c|c|}
\hline \multirow[b]{2}{*}{ No } & \multirow[b]{2}{*}{$\begin{array}{l}\text { Stateme } \\
\text { nts }\end{array}$} & \multicolumn{5}{|c|}{ Answer options } & \multirow[b]{2}{*}{ FS } & \multirow[b]{2}{*}{$\mathbf{R S}$} & \multirow[b]{2}{*}{$\begin{array}{l}\text { Percentag } \\
\text { e }\end{array}$} \\
\hline & & $\begin{array}{l}\text { VM } \\
\text { D } \\
\text { (1) }\end{array}$ & $\begin{array}{l}D \\
(2)\end{array}$ & $\begin{array}{l}\mathbf{N} \\
(3)\end{array}$ & $\begin{array}{l}\text { A } \\
(4)\end{array}$ & \begin{tabular}{|l}
$\mathbf{V}$ \\
$\mathbf{M}$ \\
$\mathbf{A}$ \\
$\mathbf{( 5 )}$
\end{tabular} & & & \\
\hline 1. & \begin{tabular}{|l|} 
You \\
make a \\
business \\
book- \\
keeping \\
well
\end{tabular} & \begin{tabular}{|l|}
19 \\
\end{tabular} & 23 & 20 & 39 & 19 & 376 & 600 & $48,33 \%$ \\
\hline & \begin{tabular}{|l|} 
Average \\
Score
\end{tabular} & & & & & & 376 & & $48,33 \%$ \\
\hline
\end{tabular}

Source: Questionnaires, 2018.

Annotation: Frequency Score $[\mathrm{FS}]=$ Answer option $\mathrm{x}$ score

Result Score $[\mathrm{RS}]=$ Number of Respondent x 5

Score $=($ FS X 100\% $):$ RS

Based on the data in the above table, it showed that majority [58] of respondents did not make good bookkeeping related to their business. This could be seen from the large number of respondents who answered the disagree [23 respondents ] and strongly disagree [ 19 respondents] respectively. Nevertheless, book-keeping in the business world is very useful for; (1) avoid mistakes in tax reporting; (2) avoid audit risk; (3) improve financial and management analysis; and (4) get tax reduction potential.

The respondents' statement regarding this had score of 376 , which fell into the category of sufficient.

Next, the second indicator of the internal process dimension which would be discussed was the procurement system.

\subsection{Goods Procurement System}

Procurement of goods and raw materials will support business continuity. If the system for the procurement of goods and raw materials is smooth, it will have a good impact on related the small and medium businesses. Table below indicated the respondents' answers.

Table 17. Goods procurement system

\begin{tabular}{|c|c|c|c|c|c|c|c|c|c|}
\hline \multirow[b]{2}{*}{$\begin{array}{l}\mathbf{N} \\
\mathbf{o}\end{array}$} & \multirow[b]{2}{*}{$\begin{array}{l}\text { Statement } \\
\mathrm{s}\end{array}$} & \multicolumn{5}{|c|}{ Answer options } & \multirow[b]{2}{*}{ FS } & \multirow[b]{2}{*}{$\mathbf{R S}$} & \multirow[b]{2}{*}{$\begin{array}{l}\text { Percentag } \\
\text { e }\end{array}$} \\
\hline & & \begin{tabular}{|l} 
VM \\
D \\
$(\mathbf{1})$ \\
\end{tabular} & \begin{tabular}{|l|}
$D$ \\
$(2$ \\
) \\
\end{tabular} & \begin{tabular}{|l|}
$\mathbf{N}$ \\
$(3$ \\
) \\
\end{tabular} & \begin{tabular}{|l|}
$A$ \\
$(4$ \\
) \\
\end{tabular} & \begin{tabular}{|l} 
VM \\
A \\
$(\mathbf{5})$ \\
\end{tabular} & & & \\
\hline 1. & $\begin{array}{l}\text { The system } \\
\text { for } \\
\text { procuring } \\
\text { goods and } \\
\text { raw } \\
\text { materials is } \\
\text { more } \\
\text { smoothly }\end{array}$ & 3 & 19 & 30 & 63 & 5 & $\begin{array}{l}40 \\
8\end{array}$ & $\begin{array}{l}60 \\
0\end{array}$ & $56,67 \%$ \\
\hline
\end{tabular}

\begin{tabular}{|l|l|l|}
\hline $\begin{array}{l}\mathbf{4 0} \\
\mathbf{8}\end{array}$ & & $\mathbf{5 6 , 6 7 \%}$ \\
\hline
\end{tabular}
core

Result Score $[\mathrm{RS}]=$ Number of Respondent x 5

Score $=($ FS X 100\% $):$ RS

68 out of 120 respondents [56,67\%] admitted that it was true that their goods and raw materials for procurement system got more smoothly since they were empowered. The main cause was due to capital adequacy to make orders. The average score for this indicator had been

408 , which was included in the sufficient category.

The third indicator of the internal process dimension that was going to be discussed had been the filing system.

\subsection{Filing System}

Archive is the placement of papers in a good place of storage according to predetermined rules in such a way that each paper if needed can be rediscovered easily and quickly. In the world of filing, archives are often in the forms of paper notes, both sales and memorandum notes purchase. Note is also one of the important components in the business field, in addition to book-keeping. This note is very useful for the recapitulation of financial reports from related to small-medium businesses. Concerning the filing system of the small-medium businesses under the empowerment program, see the table below.

Table 18. Filing system

\begin{tabular}{|c|c|c|c|c|c|c|c|c|c|}
\hline \multirow[b]{2}{*}{ No } & \multirow{2}{*}{$\begin{array}{l}\text { Statement } \\
\text { s }\end{array}$} & \multicolumn{5}{|c|}{ Answer options } & \multirow[b]{2}{*}{ FS } & \multirow[b]{2}{*}{$\mathbf{R S}$} & \multirow[b]{2}{*}{$\begin{array}{l}\text { Perce } \\
\text { ntage }\end{array}$} \\
\hline & & $\begin{array}{l}\text { VMD } \\
(1) \\
\end{array}$ & $\begin{array}{l}\text { D } \\
(2) \\
\end{array}$ & $\begin{array}{l}\mathbf{N} \\
(3)\end{array}$ & $\begin{array}{l}\text { A } \\
(4)\end{array}$ & $\begin{array}{l}\text { VMA } \\
\text { (5) }\end{array}$ & & & \\
\hline 1. & $\begin{array}{l}\text { The filing } \\
\text { system of } \\
\text { your } \\
\text { business } \\
\text { has been } \\
\text { getting } \\
\text { better }\end{array}$ & 20 & 24 & 11 & 47 & 18 & 379 & 600 & $\begin{array}{l}54.16 \\
\%\end{array}$ \\
\hline & $\begin{array}{l}\text { Average } \\
\text { Score }\end{array}$ & & & & & & 379 & & $\begin{array}{l}54.16 \\
\%\end{array}$ \\
\hline
\end{tabular}

Source: Questionnaires, 2018.

Annotation: Frequency Score $[\mathrm{FS}]=$ Answer option $\mathrm{x}$ score

Result Score $[\mathrm{RS}]=$ Number of Respondent $\times 5$

Score $=($ FS X 100\% $):$ RS

Seeing the data in table 18, shows that of the 120 respondents who answered as much as 55 of them said they agreed if the memorandum of purchase and sale of goods were stored properly. Respondents' answers are in line with the opinion of The Liang Gie that the archive is a scripting letter which is stored systematically because it has a utility so that whenever needed can be easily rediscovered.

The respondent's statement regarding the above questionnaire had a score of 379 , which was included in the sufficient category.

The conclusion of the three indicators on the third dimension of the $\mathrm{Y}$ variable is 
that there were 58 respondents from 120 respondents stating that they made business bookkeeping well, and there were 68 out of 120 respondents stating that the procurement system for raw materials was smoother, then 65 out of 120 respondents states that the memorandum of purchase and sale of goods is stored properly. The percentage of respondents from the first indicator of a well-made business bookkeeping is $48.33 \%$. Then the second indicator produced a percentage of $56.67 \%$ regarding the system of procurement of goods or raw materials more smoothly. Furthermore, the last indicator on the internal process dimension, namely the purchase and sale notes, are stored well, resulting in a percentage of $54.16 \%$. The sum of the percentages of the first, second, and third indicators of the $\mathrm{Y}$ variable is divided by 3 , namely $(48.33+56.67+54.16): 3$ $=53.05$. So the percentage of the third dimension of the $\mathrm{Y}$ variable, namely the dimension of Cost is $53.05 \%$.

Next, the fourth dimension will be discussed, namely growth and learning, the first indicator of sales of goods and business products has increased.

\section{Growth and Learning}

\subsection{Level of Marketing and Sales}

Sales of goods are elements or parts that are interconnected and function together according to their respective duties to achieve the stated goals. The stated goal is to sell goods and business products, which must be pursued to increase sales from time to time. The following will be presented by the respondent's questionnaire answers regarding the above matters through table below.

Table 19. Level of marketing and sales

\begin{tabular}{|c|c|c|c|c|c|c|c|c|c|}
\hline \multirow[b]{2}{*}{ No } & \multirow{2}{*}{$\begin{array}{l}\text { Statemen } \\
\text { ts }\end{array}$} & \multicolumn{5}{|c|}{ Answer options } & \multirow[b]{2}{*}{ FS } & \multirow[b]{2}{*}{$\mathbf{R S}$} & \multirow{2}{*}{$\begin{array}{l}\text { Percent } \\
\text { age }\end{array}$} \\
\hline & & $\begin{array}{l}\text { VMD } \\
\text { (1) }\end{array}$ & $\begin{array}{l}\mathrm{D} \\
(2)\end{array}$ & $\begin{array}{l}\mathbf{N} \\
(\mathbf{3})\end{array}$ & $\begin{array}{l}A \\
\text { (4) }\end{array}$ & \begin{tabular}{|l|} 
VMA \\
$(5)$
\end{tabular} & & & \\
\hline 1. & $\begin{array}{l}\text { Sales of } \\
\text { your } \\
\text { business } \\
\text { goods and } \\
\text { products } \\
\text { have } \\
\text { increased } \\
\end{array}$ & 4 & 29 & 19 & 56 & 12 & 403 & 600 & $56.67 \%$ \\
\hline & \begin{tabular}{|l|} 
Average \\
Score \\
\end{tabular} & & & & & & 403 & & $56.67 \%$ \\
\hline
\end{tabular}

Source: Questionnaires, 2018.

Annotation: Frequency Score $[\mathrm{FS}]=$ Answer option $\mathrm{x}$ score

Result Score $[\mathrm{RS}]=$ Number of Respondent $\mathrm{x} 5$

Score $=($ FS X 100\% $):$ RS

Based on the data in the table above, it shows that the most dominant answer from the respondents stated that they agreed that if their sales of goods and business products had increased, the total percentage was $56.67 \%$.

The respondents' statement regarding the questionnaire above had a score of 403, which were included in the sufficient category. Next will be discussed the second indicator of the dimensions of growth and learning, namely the production of business goods has increased.

\subsection{Production Level}

Production is all activities that aim to increase or add to the use of an object, or all activities aimed at satisfying others through exchange (Partadireja, 1985: 21). Referring to the previous indicator, if the sale of goods experiences a significant increase, the production of business goods must also be increased, this is the goal so that there is no emptying of the stock if at any time consumers need. The following will be presented by the respondent's questionnaire answers regarding the above matters through Table 20 below.

Table 20. Production level

\begin{tabular}{|c|c|c|c|c|c|c|c|c|c|}
\hline \multirow[b]{2}{*}{ No } & \multirow[b]{2}{*}{$\begin{array}{l}\text { Statemen } \\
\text { ts }\end{array}$} & \multicolumn{5}{|c|}{ Answer options } & \multirow[b]{2}{*}{ FS } & \multirow[b]{2}{*}{$\mathbf{R S}$} & \multirow[b]{2}{*}{$\begin{array}{l}\text { Percenta } \\
\text { ge }\end{array}$} \\
\hline & & $\begin{array}{l}\text { VM } \\
\text { D } \\
\text { (1) } \\
\end{array}$ & $\begin{array}{l}\text { D } \\
(2)\end{array}$ & $\begin{array}{l}\mathbf{N} \\
(3)\end{array}$ & $\begin{array}{l}\text { A } \\
(4)\end{array}$ & $\begin{array}{l}\mathrm{VM} \\
\mathbf{A} \\
(\mathbf{5}) \\
\end{array}$ & & & \\
\hline 1. & $\begin{array}{l}\text { Productio } \\
n \quad \text { of } \\
\text { business } \\
\text { goods has } \\
\text { increased }\end{array}$ & 3 & 29 & 14 & 63 & 11 & 410 & 600 & $61.67 \%$ \\
\hline & $\begin{array}{l}\text { Average } \\
\text { Score }\end{array}$ & & & & & & 410 & & $61.67 \%$ \\
\hline
\end{tabular}

Source: Questionnaires, 2018.

Annotation: Frequency Score $[\mathrm{FS}]=$ Answer option $\mathrm{x}$ score

Result Score $[\mathrm{RS}]=$ Number of Respondent $x 5$

Score $=($ FS X 100\% $):$ RS

In Table 18 the data presented, shows that out of 120 respondents the majority agree if the production of their business goods has increased. Ahyari (2002: 150) says that increasing production of a company must meet several factors; (1) availability of basic materials; (2) availability of the capacity of machines owned; (3) availability of labor; (4) the amount of demand for production; and (5) availability of production factors.

The respondent's statement regarding the questionnaire above had a score of 410, which was included in the sufficient category. Next will be discussed the third indicator of the dimensions of growth and learning, namely experience and insight increases.

\subsection{Experience and Insight}

According to Notoadmodjo (2010: 188) experience is a way to obtain the truth of knowledge by repeating the knowledge gained in solving problems encountered in the past. The following will be presented by the respondent's questionnaire answers regarding the above matters through Table 21 below.

Table 21. Experience and insight

\begin{tabular}{|l|c|c|c|c|c|}
\hline No & $\begin{array}{c}\text { State } \\
\text { ments }\end{array}$ & Answer options & S & S & $\begin{array}{c}\text { Percen } \\
\text { tage }\end{array}$ \\
\hline
\end{tabular}




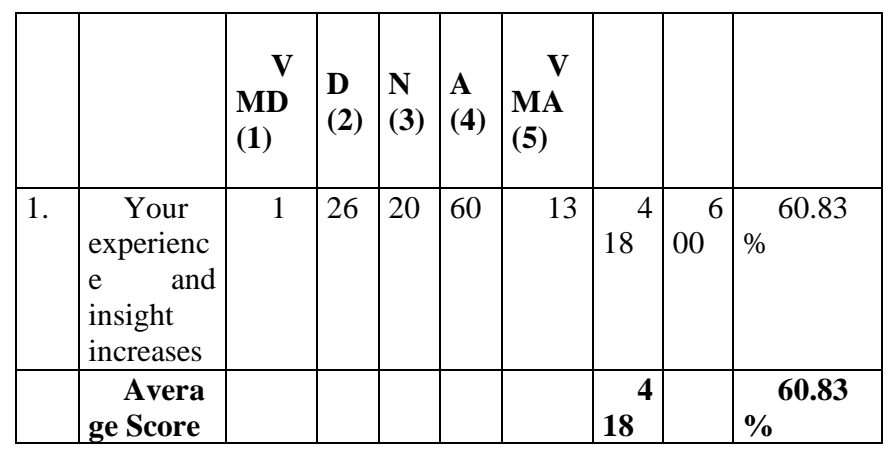

Source: Questionnaires, 2018.

Annotation: Frequency Score $[\mathrm{FS}]=$ Answer option $\mathrm{x}$ score

Result Score $[\mathrm{RS}]=$ Number of Respondent x 5

Score $=($ FS X 100\% $):$ RS

Referring to the data in the table above, most of the total $100 \%$ said they would agree if their experiences and insights increased.

The respondent's statement regarding the questionnaire above has a score of 418 , which is included in the good category. Next will be discussed the last indicator of the dimensions of growth and learning, namely knowledge about business increases.

\subsection{Knowledge}

Knowledge is information that is known or realized by a person based on sensory observation (Tjandra, 2004: 35). In this case, the knowledge in question is knowledge of the business obtained by business actors from the training provided by the Cooperative Office. This knowledge is expected not only to be accepted but also can be improved. The following will be presented by the respondent's questionnaire answers regarding the above matters through Table 22 below.
Table 22. Knowledge

\begin{tabular}{|c|c|c|c|c|c|c|c|c|c|}
\hline \multirow[b]{2}{*}{ No } & \multirow[b]{2}{*}{$\begin{array}{c}\text { State } \\
\text { ments }\end{array}$} & \multicolumn{5}{|c|}{ Answer options } & \multirow[b]{2}{*}{$S^{F}$} & & \multirow[b]{2}{*}{$\begin{array}{l}\text { Percen } \\
\text { tage }\end{array}$} \\
\hline & & $\begin{array}{l}\text { V } \\
\text { MD } \\
\text { (1) }\end{array}$ & $\begin{array}{l}D \\
(2)\end{array}$ & $\begin{array}{l}\mathbf{N} \\
(3)\end{array}$ & $\begin{array}{l}\text { A } \\
\text { (4) }\end{array}$ & $\begin{array}{l}\text { V } \\
\text { MA } \\
(5)\end{array}$ & & & \\
\hline 1. & \begin{tabular}{l}
\multicolumn{1}{c}{ Knowl } \\
edge \\
about \\
business \\
increases
\end{tabular} & 1 & 22 & 21 & 65 & 11 & $23^{4}$ & $00^{6}$ & $\%^{63.33}$ \\
\hline & \begin{tabular}{|r|} 
Avera \\
ge Score
\end{tabular} & & & & & & $23^{4}$ & & $\%^{63.33}$ \\
\hline
\end{tabular}

Source: Questionnaires, 2018.

Annotation: Frequency Score $[\mathrm{FS}]=$ Answer option $\mathrm{x}$ score

Result Score $[\mathrm{RS}]=$ Number of Respondent $x 5$

Score $=($ FS X 100\% $):$ RS

Referring to the data in the table above, 76 respondents from all 120 respondents said they agreed if the knowledge about their business increased. Knowledge can be obtained in various ways, as mentioned by Soekidjo (2005: 76), namely; (1) how to try sala; (2) the way of power or authority; and (3) personal experience.

The last indicator of growth and learning dimension was knowledge. It had been scored 423 which was included in good category.

From the above analysis, it could be concluded that, on average, the dimension of growth and learning was good because the score was 413 .

In terms of descriptive statistics analysis, it was positively recapitulated that both variables empowerment program implementation and the performance of small-medium businesses were good. The scores were 458 and 413 .

Table 23. Recapitulation of Empowerment Program Implementation and the Performance of Small and Medium Businesses

\begin{tabular}{|c|c|c|c|}
\hline No & Variable: Empowerment Program Implementation & & \\
\hline \multirow[t]{6}{*}{1} & $\begin{array}{l}\text { Dimension: The degree of compliance } \\
\text { with } 5 \text { indicators: }\end{array}$ & Score & Creteria \\
\hline & The needed documents & 537 & Very good \\
\hline & The requirement fulfillment & 528 & Very good \\
\hline & The needed documents completeness & 537 & Very good \\
\hline & Loan money appropriateness & 422 & Good \\
\hline & Available training participation & 453 & Good \\
\hline \multirow[t]{3}{*}{2} & $\begin{array}{l}\text { Dimension: The smoothness of routine functions } \\
\text { with } 2 \text { indicators: }\end{array}$ & & \\
\hline & Production process smoothness & 453 & Good \\
\hline & Marketing smoothness & 389 & Sufficient \\
\hline \multirow[t]{3}{*}{3} & $\begin{array}{l}\text { Dimension: The desired target and impact } \\
\text { with } 2 \text { indicators: }\end{array}$ & & \\
\hline & More and broader product and service marketing & 401 & Sufficient \\
\hline & Better Welfare & 406 & Sufficient \\
\hline \multicolumn{2}{|c|}{ Average score for Empowerment Program Implementation } & 458 & Good \\
\hline No & Variable: The Performance of the businesses & & \\
\hline
\end{tabular}


International Conference on Recents Advancements in Engineering and Technology (ICRAET-18) |15th and 16th March 2019|Siddhartha Institute of Technology \& Sciences, Telangana, India.

\begin{tabular}{|c|c|c|c|}
\hline \multirow[t]{3}{*}{1} & Dimension: Finance with 2 indicators: & Score & Creteria \\
\hline & Return on business capital & 414 & Good \\
\hline & Business Profit & 445 & Good \\
\hline \multirow[t]{3}{*}{2} & Dimension: Customer with 2 indicators: & & \\
\hline & Customer group & 425 & Good \\
\hline & Customer mobility & 441 & Good \\
\hline \multirow[t]{4}{*}{3} & Dimension: Internal Process with 3 indicators: & & \\
\hline & Book-keeping System & 376 & Sufficient \\
\hline & Goods Procurement System & 408 & Sufficient \\
\hline & Filing System & 379 & Sufficient \\
\hline \multirow[t]{5}{*}{4} & Dimension: Growth and Learning with 4 indicators: & & \\
\hline & Level of Marketing and Sales & 403 & Sufficient \\
\hline & Production Level & 410 & Sufficient \\
\hline & Experience and Insight & 418 & Good \\
\hline & Knowledge & 423 & Good \\
\hline \multicolumn{2}{|c|}{ Average score for The Performance of the businesses } & 412 & Good \\
\hline
\end{tabular}

The analysis of descriptive statistics was going to be followed by the analysis of explanative [confirmatory] technique.

C. Data Analysis by Using Explanative (Confirmatory) Technique

The questions raised were: Was there any influence of small and medium enterprises empowerment program implementation towards the performance of the small and medium businesses? How much was the influence of small and medium enterprises empowerment program implementation towards the performance of the small and medium businesses?

To answer the first question, it was necessary to find out the value of correlation coefficient by making use of simple linear regression approach by using SPSS program version 25.0 for windows. The first step was testing whether the data were normally distributed. For this, see the following figure.

\section{Normal P.P Plot of Regression Standardized Residual}

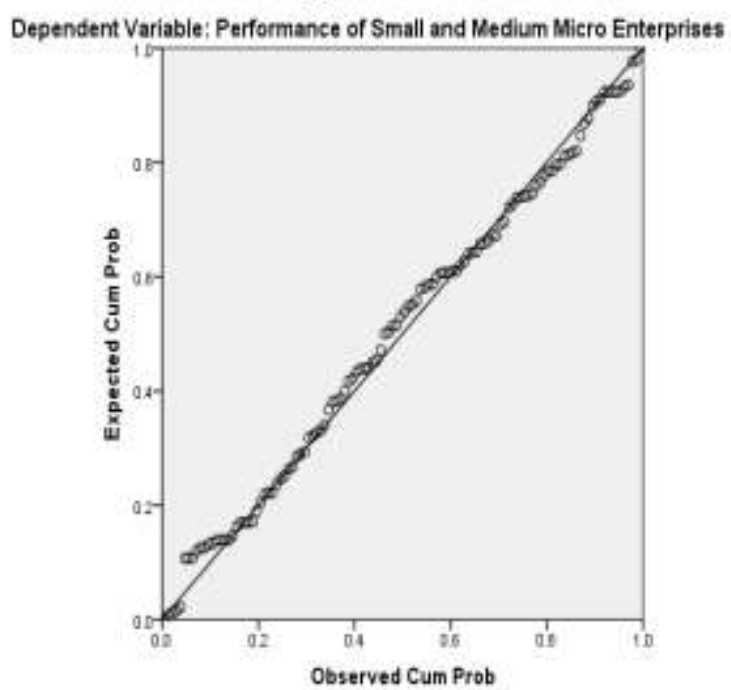

Fig. 2Data Distribution Normality

The graph showed that data were concentrated around linear lines. It could be concluded that data were normally distributed.
Then, the result of hypothesis test by using t test denoted that $\mathrm{t}=10,972$, while $\mathrm{t}$ table $=1,645$ which was obtained from the degree of freedom $(\mathrm{df})=\mathrm{N}-2$ where $120-2=118$ with significance level was $5 \%$. Because $\mathrm{t}$ was more that $\mathrm{t}$ table $[10,972>1,645] 1,645$, it meant that $\mathrm{H}_{1}$ was accepted, while $\mathrm{H}_{0}$ is rejected. Hypothesis test could be seen from bell curve in the Figure 3 below:

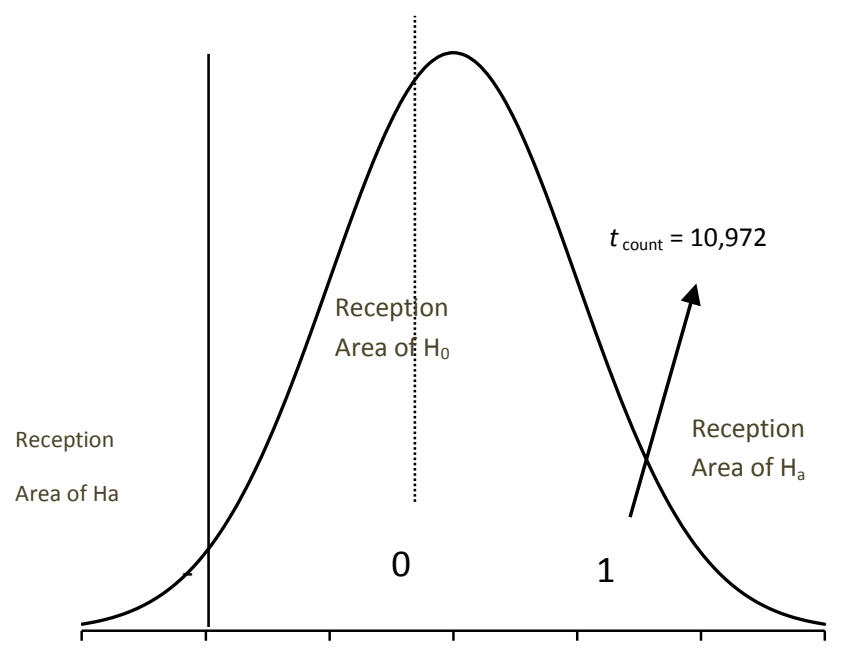

Fig. 3. Bell curve for hypothesis testing

From the curve above, it could be drawn a conclusion that there was a positive and significant influence of empowerment program implementation towards the performance of small and medium business empowered by Cooperative and Small and Medium affairs Office of Ogan Ilir Regency.

Tthe following is a recapitulation of the results of analysis by means of simple linear regression. 
Table 24. Recapitulation of Results of Simple Linear Regression Analysis Using SPSS Version 25.0

\begin{tabular}{|c|c|c|}
\hline No. & & \\
\hline 1. & $\begin{array}{l}\text { Correlation } \\
\text { Coefficient (Value } \\
\text { R) of } 0.711\end{array}$ & $\begin{array}{l}\text { The interpretation was that the } \\
\text { relationship between the two variables } \\
\text { had been in strong correlation } \\
\text { category. }\end{array}$ \\
\hline 2. & $\begin{array}{l}\text { The Determination } \\
\text { Coefficient }(\mathrm{R} \\
\text { Square) was } 0.505\end{array}$ & $\begin{array}{l}\text { It meant the influence of } \\
\text { empowerment program } \\
\text { implementation towards the } \\
\text { performance of the businesses had } \\
\text { been } 50.5 \% \text {. While another } 49,5 \% \text { was } \\
\text { influenced by other factors (epsilon) } \\
\text { which were not examined in this study. }\end{array}$ \\
\hline 3 & 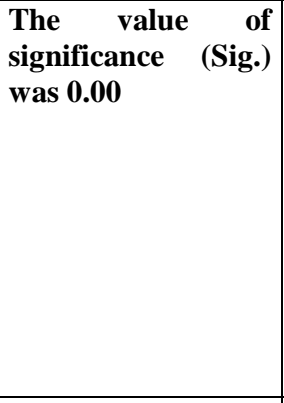 & $\begin{array}{l}\text { The significance test results from this } \\
\text { table were used to determine the level } \\
\text { of significance or linearity of the } \\
\text { regression. Criteria could be } \\
\text { determined based on the test of } \\
\text { significance value. The Sig value was } \\
0.00 \text {. Since } 0.00<0.05 \text { (significance } \\
\text { criteria). Thus the regression equation } \\
\text { model was significant, or the } \\
\text { regression equation model met the } \\
\text { criteria. }\end{array}$ \\
\hline 4. & $\begin{array}{l}\text { Simple Linear } \\
\text { Regression } \\
\text { Coefficient } \\
\text { with the value } \\
\text { constant (a) of } \\
18,831 \\
\text { and the value of } \\
\text { empowerment } \\
\text { program } \\
\text { implementation (b / } \\
\text { regression } \\
\text { coefficient) of } 0.502\end{array}$ & $\begin{array}{l}\text { The constant value of } 18,831 \text { implied } \\
\text { that the consistent value of the variable } \\
\text { small-medium businesses performance } \\
\text { was } 18,831 \text {. The regression coefficient } \\
\mathrm{X} \text { of } 0.502 \text { stated that every } 1 \% \\
\text { addition to the value of the } \\
\text { empowerment program } \\
\text { implementation, the value of small- } \\
\text { medium businesses performance } \\
\text { increased by } 0.502 . \text { The regression } \\
\text { coefficient was positive, so it could be } \\
\text { said that the direction of the influence } \\
\text { of variable X towards Y was positive. }\end{array}$ \\
\hline 5. & $\begin{array}{l}\text { The value of } t \\
\text { count is equal to } \\
10,972\end{array}$ & $\begin{array}{l}\text { There is a significant effect of variable } \\
\mathrm{X} \text { towards Y variable if } \mathrm{t} \text { count }>\mathrm{t} \\
\text { table. Based on the } \mathrm{t} \text { test it was known } \\
\text { that the } \mathrm{t} \text {-count value was } 10,972>\mathrm{t} \\
\text { table } 1,645 \text { so that it could be } \\
\text { concluded that the Empowerment } \\
\text { Program Implementation variable } \\
\text { influenced the Performance of Small } \\
\text { and Medium Micro Enterprises } \\
\text { variable. So that it can be concluded } \\
\text { that the variable } \mathrm{X} \text { has a significant } \\
\text { effect on the variable } \mathrm{Y} \text {. Then H1 is } \\
\text { accepted and } \mathrm{H} 0 \text { is rejected. }\end{array}$ \\
\hline
\end{tabular}

Source: Processed from primary data through SPSS version 25.0, October 2018

From table 24 above, it could be seen that Empowerment Program Implementation on small and medium businesses influenced the Performance of the businesses. The influence had been as much as $50,5 \%$. See the following model.

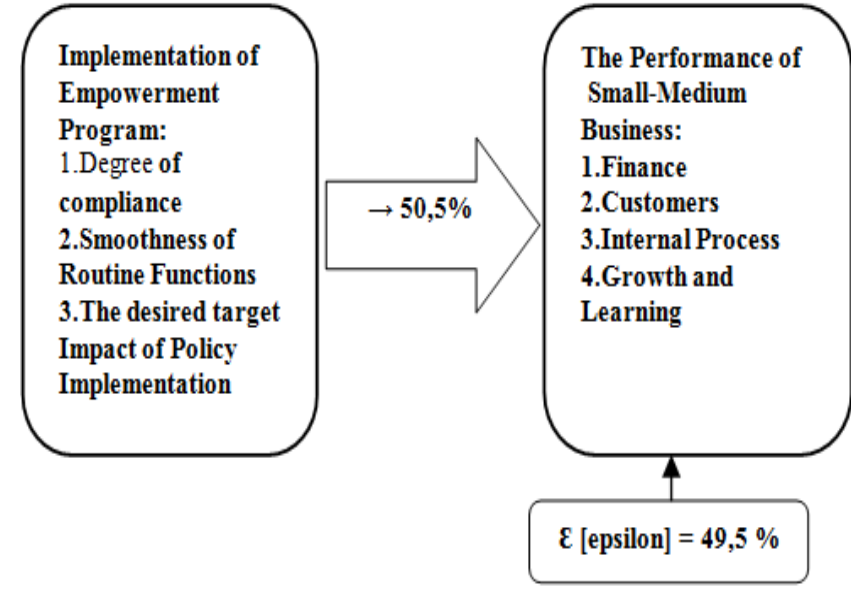

Fig. 4The Model of Empowerment Program Implementation affected the Performance of Small and Medium Businesses

\section{CONCLUSION}

In terms of descriptive quantitative (descriptive statistics) analysis technique, it showed that Empowerment Program Implementation on small-medium businesses empowered by Cooperative and Small-Medium Affairs Office of Ogan Ilir Regency was was scored 458 which meant good. The Performance of the small-medium businesses had been good, too. The score was 412 .

Furthermore, explanative [confirmatory] analysis by making use of simple linear regression with SPSS program 25.0 showed that the Empowerment Program Implementation positively and significantly influenced the Performance of Small and Medium Micro Enterprises.

It was proved where $\mathrm{t}$ value was more than $\mathrm{t}$ table $[10,972>\mathrm{t}$ table 1,645]. Forward, the determination coefficient (R Square) was 0.505. It meant the influence of Empowerment Program Implementation towards the Performance of Small and Medium businesses was as much as $50,5 \%$. Another $49,5 \%$ was influenced by other factors which were not examined in this study [E epsilon].

\section{SUGGESTION}

based on the results of the discussion and calculation above, the recommended advice to the ogan ilir cooperative service is as follows:

1) The cooperative and small-medium business affairs office is suggested to help more to market small-medium businesses' products by introducing the products in more exhibitions on local, national, and, even, international levels. more markets gives more benefits

2) The small-medium business to pay better attention towards internal process for better book-keeping system, filing system, and goods procurement system. 


\section{REFERENCES}

Books :

1. Aditama, Yoga Tjandra. 2004. "Manajemen Administrasi Rumah Sakit, Jakarta: UI Press

2. $\quad$ Ahyari, Agus. 2002. "Manajemen Produksi Perencanaan Sistem Produksi Buku II".

3. Yogyakarta: BPFE Yogyakarta.

4. Assauri, Sofian. 2004. "Manajemen Produksi dan Operasi”. Edisi Revisi. Lembaga Penerbit Fakultas Ekonomi, Universitas Indonesia. Jakarta.

5. Alex S, Nitisemito. 1996. "Managemen Personalia". Bandung: Ghalia Indonesia

6. Bernadin, H. John. 1998. "Human Resource Management: An Exprential Approach".

7. Irwin/McGraw-Hill.

8. Budi, Triton P. 2006. "SPSS13.0 Terapan: Riset Statistik Parametrik”. Yogyakarta: C.V

9. Andi Offset.

10. Greenberg, Paul. 2010. "Customer Relationship Management as the Spread of Light :Fourth

11. Edition". Jakarta: Rineka Cipta.

12. Griffin, Jill. 2003. "Customer Loyalty : how to earn it, how to keep it". Jakarta: Erlangga.

13. Hanafi, Mahmud M. 2010. Manajemen Keuangan. Cetakan kelima. Yogyakarta:BPFE

14. Hanggana, Sri. 2006. "Akuntansi Biaya". Surakarta: Mediatama.

15. Jauch, Lawrence R. dan William F. Glueck, (1998), "Manajemen Strategis dan Kebijakan Perusahaan", Edisi ketiga, Erlangga, Jakarta.

16. Kotler, Philip. 2001. Manajemen Pemasaran: Analisis, Perencanaan, Implementasi dan Kontrol. Jakarta: PT. Prehallindo.

17. Nafarin, M. 2007. "Penganggaran Perusahaan". Jakarta:Salemba Empat.

18. Notoadmojo, Soekidjo. 2010. "Metodologi Penelitian

2005. "Metodologi Penelitian Kesehatan”. Jakarta: PT Rineka.

20. Suyatno, Thomas. 2007. "Dasar-dasar Perkreditan". Jakarta: Gramedia Pustaka Bersama.

21. Thomas, Rolling G. 1957. "Our Modern Banking and Monetary System".

22. Tu'u, Tulus. 2004. "Peran Disiplin Pada Perilaku dan Prestasi Siswa”. Jakarta: PT

23. Grasindo.

24. Partadireja, Ace. 1985. "Pengantar Ekonomi". Yogyakarta: BPFE-UGM.

25. Procton, J. H. Dan Thornton, W. M. (Diterjemahkan Mulyana Sugandi). 1983. "Latihan

26. Kerja”. Jakarta: Bina Aksara.

\section{Journal:}

1. Sudaryanto. 2011. "The Need for ICT-Education for Manager or Agribusinessman to Increasing Farm Income : Study of Factor Influences on Computer Adoption in East Java Farm Agribusiness". International Journal of Education and Development, JEDICT, Vol 7 No 1 halm. 56-67.

2. Surianto, Agung dan Aisyah, Nurul. 2009. "Pengaruh Penerapan Experiential Marketing Strategik Terhadap Kepuasan". Journal of Logos Vol. 6, No. 2. Universitas Muhammadiah Gresik.

\section{Internet:}

1. Kotler, Philip (2011, March 29). Marketing Definitions. Heidin Cohen: Actionable Marketing Guide. https://heidicohen.com/marketing-definition.

2. https://www.salesfusion.com/resource/measuringmarketing-effectiveness-5-metrics-need-track Kesehatan”. Jakarta: PT Rineka.

\section{AUTHORS PROFILE}

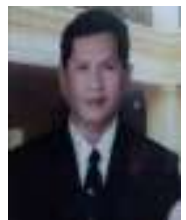

Andy Alfatih was born in Musi Banyuasin, South Sumatera, on December 24, 1960. In 1989 graduated from under graduate degree in field public administration, University of Sriwijaya, South Sumatera Indonesia Graduated in 1996 from master degree of public administration from Flinders University, South Australia, Australia. In 2010, graduated from Doctoral degree infield Public Administration, University of Padjajaran, Bandung, West Java, Indonesia.

He is a lecturer in Public Administration Department, Faculty of Social and Political Sciences and Public Administration Post Graduate Program, Sriwijaya University, Palembang City, South Sumatera, Indonesia Published books and articles are : 1) The Effectiveness of Kambang Iwak Besak Park as A Public Space, In Palembang City, Indonesia (Scopus Journal in Advanced Science Letters. Volume 23, Number 5, May 2017, pp.4904-4907), DOI:https://doi.org/10.1166/asl.2017.8952. 2) Journal indexed by Copernicus on International Journal of Social Science and Humanity, Public Policy on Green Open Space Development in Palembang City, Indonesia. Volume 08. Nomor 2, February, 2018, pp. 55-58, doi 10.18178/ijssh.2018.8.2.933. 3) Research Methodology, (Teaching Modul, Faculty of Social and Political Sciences, Sriwijaya University, 2010) Current and previous research interests are about public policy in local government.

Dr. Alfatih active as both speaker and moderator since 2012 in Eastern Regional Organization for Public Policy Administration (EROPA). Active as both speaker and moderator since 2012 in International Conference on Local Government (ICLG). Active as both speaker and moderator since 2012 in Indonesian Association for Public Administration (IAPA). Active as speaker since 2014 in Asian Studies Association of Australia.

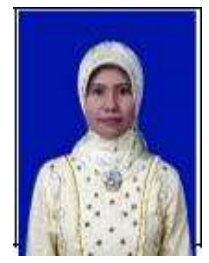

Diana D. Sartika was born in Prabumulih, South Sumatera, Indonesia, on Februari, 11 1980. In 2003 graduated from under graduate degree in field Sociology, University of Sriwijaya, South Sumatera Indonesia. Graduated in 2007 from Master degree of Sociology from Gadjah Mada University, Yogyakarta, Indonesia. In 2016 until now still studying as a Doctoral student in field Sociology, at Gadjah Mada University, Yogyakarta, Indonesia.

She is a lecturer in Sociology Department, Faculty of Social and Political Sciences, Sriwijaya University, Palembang City, South Sumatera, Indonesia. Published books and articles are : 1) The Effectiveness of Kambang Iwak Besak Park as A Public Space, In Palembang City, Indonesia (Scopus Journal in Advanced Science Letters. Volume 23, Number 5, May 2017, pp. 4904-4907) DOI:https://doi.org/10.1166/asl.2017.8952. 2) Journal indexed by Copernicus on International Journal of Social Science and Humanity, Public Policy on Green Open Space Development in Palembang City, Indonesia. Volume 08. Nomor 2, February, 2018, pp. 55-58, doi: 10.18178/ijssh.2018.8.2.933. Current and previous research interests are about Sociology, Gender and Child Studies.

Sartika active as both Regional Facilitator and Activist of Integrated Child Protection Based on Society in South Sumatera Province, Indonesia, since 2016 until now. Also active as a researcher in Centre of Gender and Child Studies, Institute for Research and Community Service, University of Sriwijaya from 2003 until now.

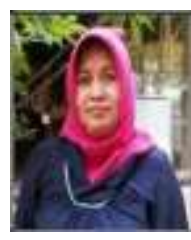

Dyah H. ENH was born in Blora, Central Java, Indonesia, on October, 02 1960. In 1986 graduated from under graduate degree in field Sociology, University of Gadjah Mada, Yogyakarta, Indonesia. Graduated in 2008 from the master degree of Public Administration from Sriwijaya University, South Sumatera, Indonesia.

She is a lecturer in Sociology Department, Faculty of Social and political Sciences, Sriwijaya University, Palembang City, South Sumatera, Indonesia. She is also a former Dean on Faculty of Social and Political Sciences, Sriwijaya University, South Sumatera, Indonesia, in 2009-2013. Published books and articles are : 1) The Effectiveness of Kambang Iwak Besak Park as A Public Space, In Palembang City,

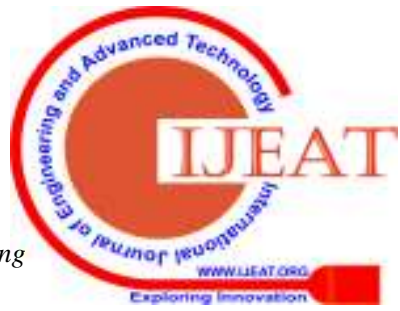


Indonesia (Scopus Journal in Advanced Science Letters. Volume 23, Number 5, May 2017, pp. 4904-4907), DOI:https://doi.org/10.1166/asl.2017.8952. 2) Journal indexed by Copernicus on International Journal of Social Science and Humanity, Public Policy on Green Open Space Development in Palembang City, Indonesia. Volume 08. Nomor 2, February, 2018, pp. 55-58, doi: 10.18178/ijssh.2018.8.2.933. 3) Implementasi Nilai-nilai Pancasila dalam Mewujudkan Pembangunan Karakter Bangsa di Perguruan Tinggi, (Padang, Indonesia, Laboratorium Sosiologi, Faculty of Social and Political Sciences, Andalas University, 2016). Current and previous research interests are about Sociology. 